\title{
Resenha de livros
}

Esta seção se destina à apresentação de resenhas de livros de interesse para a bioética.

\section{A fome e o mangue: o drama de uma descoberta}

\author{
Homens e Caranguejos \\ Castro J \\ São Paulo: Brasiliense, 1968 \\ ISBN: 9788520005392
}

A cidade do Recife, a Veneza brasileira, localizada no estado do Pernambuco, é o cenário de Homens e Caranguejos, do ilustre Josué de Castro, que de maneira tocante, relata com sutileza e sensibilidade o drama fétido e vergonhoso da fome, nas terras pobres e famintas do Nordeste brasileiro. O livro em comento enquadra-se no gênero literário romance e apresenta-se como um livro de memórias.

Em sua narrativa, pelos olhos negros e profundos de um pequeno protagonista, tudo é possível contemplar: desde a infância que insiste em vingar nos alagados da cidade do Recife, até o estranho mimetismo entre homens e caranguejos.

A referida obra conta a história da descoberta que o autor fez, ainda menino, da fome e da desigualdade; também, da percepção que teve do escanteio social sofrido pela sociedade do mangue, sempre à margem de duas estruturas econômicas que a história até hoje não costurou em um mesmo tecido: a agrária feudal e a capitalista.

A sociedade do mangue é uma coletividade imprensada entre essas duas estruturas esmagantes, e tem na fome a grande força modeladora do seu comportamento moral, dos seus valores éticos e dos seus sentimentos dominantes. Vê-los agir, falar, lutar, sofrer, viver e morrer é ver a própria carência esculpindo, com suas despóticas mãos de ferro, seus caracteres.

A história trazida pelo autor pernambucano ainda encanta com quase meio século de publicação. Além disso, os dramas vividos pelo protagonista João Paulo e sua família soam extremamente atuais para o Brasil nordestino, semiárido, miserável, analfabeto, ironicamente 
berço de um povo forte, incansável e feliz.

A genialidade de Castro é tanta, que mesmo aqueles que nunca estiveram no Nordeste, ou mesmo diante do ecossistema do mangue, podem sentir-se parte da sua narrativa. É possível, ainda, mesmo sem qualquer vinculação com o regionalismo próprio da obra, identificarse não só com as mazelas vividas pelos moradores dos mocambos, mas sobretudo sensibilizar-se com as alegrias vividas nas choças e nos casebres de barro, fincados na lama do rio Capibaribe.

Em sua obra é possível, também, observar que no ciclo misterioso do caranguejo ocorre a mais profunda simbiose entre homens e crustáceos que se arrastando, agachando, vivendo das migalhas um do outro, em meio à podridão e à lama, caminhando para trás, assemelham-se vergonhosamente em tudo, mostrando que na luta pela sobrevivência o homem tudo sofre, tudo suporta, tudo crê, tudo espera.

O douto cientista ensina ainda que não é só no banco das universidades que o aprendizado é construído. O conhecimento que ele tinha sobre a fome, a pobreza, a influência do meio no comportamento do indivíduo, bem como da vulnerabilidade humana, revelou-se, na mais tenra idade, na lida, na convivência e no contato com o semelhante.

Em seu livro, Homens e Caranguejos, Josué de Castro descreve o cenário da sua infância. A imagem do mangue atravessa sua vida e é seu primeiro campo de inquietação social, a partir do qual passará a compreender o fenômeno da fome.

Não distingue mangue de manguezal; para ele, vegetação e ecossistema se confundem. Todavia, é importante esclarecer que enquanto manguezal é um ecossistema típico de áreas costeiras alagadas e de regiões de clima tropical ou subtropical, o mangue é o tipo de vegetação predominante nos manguezais.

Sobre a vegetação do manguezal, a obra de Castro não entra em detalhes, mas por intermédio de suas narrativas, percebe-se que existe uma variedade pequena de plantas, o que faz desse ambiente algo naturalmente pouco produtivo. Todavia, em termos de ecossistema, trata-se de um meio extremamente rico, posto que abriga grandes populações de crustáceos, peixes e moluscos.

Percebeu desde a infância e registrou no livro, a estranha 
semelhança entre os moradores do mangue do rio Capibaribe e os caranguejos, ambos recobertos de lama, não adaptados à vida na cidade e famintos. Os homens sobreviviam catando caranguejos, enquanto os caranguejos se nutriam com os dejetos humanos.

O Ciclo do Caranguejo, um dos pontos altos da obra, descreve em prosa poética a vida de uma família habitante dos mangues do Recife, originária do sertão nordestino, que migrou para a cidade fugindo dos efeitos da seca, acreditando nas promessas de uma vida melhor na cidade. Sem condições de sustentar-se, restoulhes apenas a opção de instalar-se no mangue, onde o terreno não era de ninguém, mas sim de todos.

O livro conta ainda que os períodos de grandes estiagens sempre fizeram parte da rotina do sertanejo, que, na luta contra o subdesenvolvimento local e fugindo da devastação que o mata de fome ou inanição, acostumou-se a buscar em outras áreas condições mínimas de sobrevivência.

Assim, o homem da caatinga, apesar de descontente e inconformado por ter que abandonar sua terra, depois de já ter esgotado todas as suas reservas de milho e de farinha, vê-se inevitavelmente expulso do seu chão, tendo que rumar para os grandes centros urbanos do litoral nordestino, ou de outros estados brasileiros, para encontrar sua derradeira esperança de vida.

Ocorre que a esperança por uma vida longe de privações e carestias se desfaz rapidamente quando percebe que para o trabalho, mais que boa vontade, é necessária qualificação. Desta feita, em meio ao burburinho exigente e descompensado das grandes cidades, o homem simples e faminto do sertão, aconchega-se nas periferias urbanas à procura de atividades primitivas que possam garantir-lhe algum meio de sustento.

É neste contexto de marginalização progressiva que a pesca do caranguejo até hoje representa uma tábua de salvação para muitos nordestinos, fazendo, todavia, que o homem habitante do mangue, depois de inserir-se na lama pegajosa dos rios, assemelhe-se ao caranguejo e com ele possua uma profunda simbiose. Simbiose, por meio da qual se desenvolva uma interessante e sofrida relação de dependência, de onde dificilmente sairá.

O Ciclo da Fome e o Ciclo do Caranguejo, relatados com 
propriedade pelo autor, sob um determinado prisma, nos parecem indissociáveis e antagônicos. Todavia, são percebidos com simetria e exatidão quando vistos da lama, em meio à vegetação anfíbia, densa e retorcida, que brota nas terras lodosas dos rios.

As amarguras existenciais que perfazem a natureza humana, aquelas primeiras, quase pueris, que dominam o nosso imaginário muito antes de conseguirmos entendê-las, como nascer, crescer, viver e morrer, encontram no mangue a sua grande camaradagem e interseção, pois é lá que homens e caranguejos completam o seu ciclo insólito de existência.

O fato de ambos possuírem a mesma mísera condição e de serem conjuntamente inquilinos do mesmo pedaço de terra alagada, faz deles, além de escravos da angústia de sobreviver, irmãos de leite e de lama, que juntos seguem sócios, mendigando e decompondo-se, nessa imensa sociedade ofegante e oprimida.

O que mais apavora é que a fome, este antigo instrumento de matar da morte, não se verifica como um drama local, uma realidade apenas do homem que vive no mangue; muito menos algo que aflige somente o nordeste brasileiro ou as demais regiões desiguais do nosso país. A fome, essa velha conhecida do mundo, que há tempos estigmatiza, humilha e dizima, é, na realidade, um infame drama universal, patrimônio miserável da humanidade.

A fome não tem rosto e corrói silenciosamente inúmeras populações do mundo, sendo um fenômeno a cuja ação nefasta nenhum continente escapa, possuindo dois vieses assustadoramente vorazes: não comer nada e definhar de maneira vertiginosa até o fim; ou comer de maneira inadequada e entrar em regime de carências, como vemos acontecer com o homem-caranguejo.

A luta incessante pela vida encontra seu desafio máximo no mangue, pois tem na presença constante da fome o fator decisivo do comportamento moral e ético do homem, influenciando com maestria o seu pensar, o seu agir, o seu sofrer e o seu querer, retirando-o silenciosamente da condição de indivíduo para colocálo no patamar de crustáceo ou mera carcaça de vísceras verdes.

Apesar de estar entre nós, a fome não foi feita para o homem, assim como o homem não feito para a fome. O Ciclo da Fome, diferentemente do Ciclo do Caranguejo, não é natural. Na realidade, 
o primeiro é fruto das relações socioeconômicas estabelecidas pelos homens, expressão biológica máxima de males sociológicos, sendo, portanto, um flagelo fabricado pelo homem contra o próprio homem; já o segundo é fenômeno casuístico e imprevisível, mero capricho do ecossistema do mangue.

No livro Homens e Caranguejos a questão da fome é central no contexto do mangue, mas no que tange ao drama vivido no Sertão nordestino, o problema não seria permanente, mas ocorreria de forma aguda apenas nos períodos de seca, sobretudo quando se prolongava.

Castro deixou um grande legado para o povo brasileiro, e também para o mundo. Ele foi pioneiro no alerta de que a fome e o regime alimentar impróprio eram consequências da estrutura econômica e social dominante, e nada tinham a ver com a natureza ou com os fenômenos naturais.

O estudo da obra Homens e Caranguejos mostra-nos que as sociedades, independente da forma como se constituem, estão impossibilitadas de criar riqueza sem gerar pobreza, posto que o modelo que as orienta baseia-se na degradação indiscriminada da natureza e do ser, favorecendo uma visão mecanicista do homem que há tempos tem sua existência reduzida aos bens materiais que produz e possui.

Observamos, a partir dessa análise elementar -o presente documento não tem a pretensão de esgotar a complexidade da obra Homens e Caranguejos-, que é preciso articular mecanismos para desenvolver relações mais justas, verdadeiramente comprometidas e solidárias, para dar novos rumos à nossa sociedade, para que todos nela possam caber e inserir-se.

Precisamos, portanto, trabalhar a humanização do homem para além dos tempos de crise. É preciso fomentar uma consciência perene de responsabilidade pessoal, social e política em relação à vida. As intervenções bioéticas, para serem efetivas, precisam florescer para libertar, empoderar e emancipar os indivíduos e as comunidades que estejam em condição de vulnerabilidade.

Josué de Castro foi, sem dúvida, uma figura única que marcou com suas ideias e obras, tanto o cenário nacional, quanto o internacional. Homens e Caranguejos é a prova literária de que boa parte do seu 
tempo, talento e vida, foram dedicados ao entendimento do drama da fome, sempre buscando olhares e soluções para as desigualdades sociais, a miséria e todos aqueles que viviam jogados, esquecidos e marginalizados no meio do mundo.

\section{Ticiana Garcia Fernandes Vieira}

Universidade de Fortaleza, Ceará, Brasil

garciaticiana@gmail.com 